\title{
Efflux of Radioactive Nucleotides from Mouse Pancreatic Islets Prelabelled with $2{ }^{3} \mathrm{H}$-Adenosine
}

\author{
M. Welsh \\ Department of Medical Cell Biology, University of Uppsala, Uppsala, Sweden
}

\begin{abstract}
Summary. Cultured mouse pancreatic islets were prelabelled with $2-{ }^{3} \mathrm{H}$-adenosine in order to monitor the efflux pattern of radioactivity and insulin. The outflow of radioactivity decreased continuously when the islets were perifused with glu$\operatorname{cose}(1.67 \mathrm{mmol} / \mathrm{l})$. When raising the glucose concentration to $16.7 \mathrm{mmol} / \mathrm{l}$, there was a prompt inhibition of the radioactive efflux concomitant with an increased rate of insulin release. These effects were reversed when the high glucose challenge was withdrawn. Similar radioactive efflux patterns were $o b-$ tained after addition of $\alpha$-ketoisocaproic acid, leucine or pyruvate to the perifusion medium, and also when the islets were challenged with high glucose concentrations in the absence of calcium. Both antimycin A and glipizide stimulated the efflux of radioactivity, although only the addition of glipizide was accompanied by a stimulation of the insulin release. Nucleotides
\end{abstract}

constituted approximately $90 \%$ of the total effluent radioactivity. Decrease in the radioactive AMP and ADP efflux due to high glucose was furthermore found to be the cause of the observed inhibition of the total radioactive efflux. The changes in radioactive efflux induced by glucose probably reflect changes in the intracellular concentrations of AMP and ADP. It is concluded that no simple correlation exists between radioactive efflux and insulin release and that changes in the intracellular concentrations of nucleotides may be an early event in the stimulus-secretion coupling of glucose-induced insulin release.

Key words: Mouse pancreatic islets, $2{ }^{-3} \mathrm{H}$-adenosine-labelling, radioactive efflux, insulin release, nucleotides, glucose, $\alpha$ ketoisocaproic acid, glipizide, starvation.
It has been shown recently that adenosine and certain other nucleosides stimulate both the release and biosynthesis of insulin by mouse pancreatic islets [1,3,12]. Further, it has been demonstrated that culture in the presence of $10 \mathrm{mmol} / \mathrm{l}$ adenosine can maintain mouse islets in a high functional state [3]. These stimulatory effects of adenosine have been attributed to its oxidative metabolism, although one report [11] has suggested receptor effects of adenosine in isolated islets.

In a recent study [19], we have characterized adenosine uptake by mouse pancreatic islets. It was found that adenosine is readily taken up by islets and that the majority of the adenosine taken up is incorporated into the nucleotide pools. From studies of other tissues and cells it is reasonable to assume that the metabolic products of adenosine, i.e. inosine and hypoxanthine, are released from the islets. Since nucleotides may exert important regulatory functions in the B cells $[6,14]$ and AMP is in equilibrium with adenosine via a 5'-nucleotidase (E.C.3.1.3.5.) [13], the efflux of radioactivity in response to glucose and other secretagogues from islets prelabelled with $2{ }^{3} \mathrm{H}$-adenosine was examined.

\section{Materials and Methods}

\section{Chemicals}

Collagenase (type CLS) was obtained from Worthington Biochemicals, Freehold, New Jersey, USA. Bovine albumin (fraction V), 3-0methylglucose, adenosine, adenine, inosine, hypoxanthine, cyclic AMP, ITP, IDP, IMP, GTP, GDP, GMP, guanine, guanosine, l-leucine, $\alpha$-ketoisocaproic acid, l-glutamine, antimycin A, tricyclohexylammonium-phosphoenolpyruvate (PEP), firefly extracts (FLE-50), N2-hydroxyethylpiperazine-N'-2-ethanosulphonic acid (Hepes), apyrase and Tris were supplied by Sigma Chemicals, St. Louis, USA. $2-{ }^{3} \mathrm{H}$ adenosine was from the Radiochemical Centre, Amersham, Bucks, UK. D-glucose was purchased from Mallinckrodt Chemical Works, St. Louis, USA. Instagel was obtained from Packard Instruments, Downers Grove, Illinois, USA. ATP, ADP, AMP, pyruvate kinase and myokinase were from Boehringer Mannheim, FRG. The medium RPMI 1640 was supplied by Flow Laboratories, Irvine, Ayrshire, UK. Penicillin and streptomycin were from Glaxo Laboratories, Greenford, Mid- 
dlesex, UK. Hank's solution, TC 199 and calf serum were obtained from Statens Bakteriologiska Laboratorium, Stockholm, Sweden. Glipizide was a gift from Carlo Erba, Milano, Italy. All other chemicals used, as well as the silica gel coated glass plates, were from E. Merck, Darmstadt, FRG.

\section{Islet Preparation}

Islets were isolated from male NMRI-mice, after overnight starvation, by means of a collagenase digestion technique [9]. After isolation, the islets were collected and cultured for 2-7 days in medium RPMI 1640 [2] supplemented with $10 \%$ calf serum and glucose $(11.1 \mathrm{mmol} / \mathrm{l})$ before being used in the various experiments. In some experiments, islets from $65 \mathrm{~h}$ starved mice were isolated and used directly.

\section{Islet Pre-incubation with 2- ${ }^{3} \mathrm{H}$-Adenosine}

Islets ( $n=25-75$ ) were incubated for $45 \mathrm{~min}$ at $37^{\circ} \mathrm{C}_{\text {in }} \mathrm{CO}_{2}$ : ambient air $(5: 95)$ in Hepes-buffered glucose-free Krebs Ringer salt solution (100 $\mathrm{ul}$ ) supplemented with $2-{ }^{3} \mathrm{H}$-adenosine $(0.1 \mathrm{mmol} / \mathrm{L}, 1.24-10 \mathrm{Ci} /$ $\mathrm{mmol}$ ) as described previously [19]. In four experiments, 60 islets were pre-incubated $6 \mathrm{~h}$ in medium TC 199 (glucose $5.5 \mathrm{mmol} / 1$ ) supplemented with $2-{ }^{3} \mathrm{H}$-adenosine $(0.1 \mathrm{mmol} / 1,10 \mathrm{Ci} / \mathrm{mmol})$. After pre-incubation, the islets were rapidly washed four times at $4^{\circ} \mathrm{C}$ in the uptake me$\operatorname{dium}(200 \mu \mathrm{l})$ without labelled adenosine.

\section{Perifusion Experiments}

In these studies, prelabelled islets were pooled and $60-150$ islets were transferred into each perifusion chamber. The islets were perifused at $37^{\circ} \mathrm{C}$ for $15 \mathrm{~min}$ with glucose ( $1.67 \mathrm{mmol} / \mathrm{l}$, unless otherwise stated) in a Hepes-buffered Krebs Ringer bicarbonate salt solution supplemented with bovine serum albumin $(0.5 \mathrm{mg} / \mathrm{ml})$, before additions were made as described in the figures. The media were always gassed with $95 \% \mathrm{O}_{2} / 5 \% \mathrm{CO}_{2}$. The flow rate was $1 \mathrm{ml} / \mathrm{min}$. All radioactive efflux values were calculated as percentages of the average efflux rate between minutes 11 and 15 . Aliquots $(900 \mu \mathrm{l})$ of all fractions were measured by liquid scintillation after addition of Instagel $(5 \mathrm{ml})$ and the remaining $100 \mu \mathrm{l}$ were used for insulin determination [7].

\section{Thin-layer Chromatographic Separation of Islet Extracts}

Islets prelabelled with adenosine were perifused as above. At given times, the filter with the islets was quickly transferred into $10 \%$ trichloroacetic acid ( $\mathrm{w} / \mathrm{v}, 100 \mu \mathrm{l})$, containing bromocresyl green (20 parts/ million) as an indicator and extracted at $0^{\circ} \mathrm{C}$. In some experiments freeze-dried effluent samples were extracted at room temperature. The extraction was allowed to proceed for $20-30 \mathrm{~min}$ before $\mathrm{K}_{2} \mathrm{CO}_{2}$ ( $4 \mathrm{~mol} / \mathrm{l}$ ) was added to bring about a colour-change of the indicator ( $\mathrm{pH} 4)$. Nucleotides and nucleosides were then separated as described previously [17]. Samples of $40 \mu \mathrm{l}$ were applied to silica gel coated glass plates $(20 \times 20 \mathrm{~cm}$ or $5 \times 20 \mathrm{~cm})$ containing a fluorescence indicator $\left(F_{254}\right)$. The plates were developed for $3 \mathrm{~h}$ in a mixture of isobutylalcohol-amyl alcohol-ethoxy ethanol-ammonia and glass distilled water $(15: 10: 30: 15: 25$ by volume). Standards were run in parallel and located with ultraviolet light. Samples were scraped off the gel carefully, according to the localization of the standards, and transferred to scintillation vials. Water $(2 \mathrm{ml})$ was added to each sample $30 \mathrm{~min}$ before addition of Instagel $(2.5 \mathrm{ml})$ for counting in a liquid scintillation spectrometer. The Rfvalues were as follows: GTP $=0.22 ; \mathrm{ATP}, \mathrm{GDP}, \mathrm{ITP}$ $=0.35 ; \mathrm{ADP}, \mathrm{IDP}, \mathrm{GMP}=0.42 ; \mathrm{IMP}=0.46 ; \mathrm{AMP}=0.53 ;$ Inosine, guanosine, guanine $=0.67$; adenosine, hypoxanthine, cyclic $\mathrm{AMP}=$ $0.70 ;$ adenine $=0.78$. GTP and IMP were not separated. The ATP-, ADP-, AMP-, inosine-, adenosine- and adenine-fractions contained all other nucleotides and nucleosides according to the Rf values above. Control experiments showed that islets did not contain any measurable amounts of radioactive GTP.

\section{ATP, ADP and AMP Measurements}

These measurements were performed using a luciferase technique as described previously [20]. Islets were incubated and freeze-dried as described in the Table 3 legend. The freeze-dried islets were rapidly extracted with $\mathrm{NaOH}(0.02 \mathrm{~mol} / 1,40 \mu \mathrm{l})$ and subsequently heated at $60^{\circ} \mathrm{C}$ for $15 \mathrm{~min}$ to destroy remaining enzyme activity. Samples $(4.9 \mu \mathrm{l})$ were diluted with Tris $(0.1 \mathrm{~mol} / \mathrm{l}, 10.9 \mu \mathrm{l})$, containing EDTA $(5 \mathrm{mmol} / \mathrm{h}$, $\mathrm{pH} \mathrm{8.0)}$ before measurements of ATP as described by Wettermark et al. [20]. For ADP and AMP determinations, islet extracts $(1.95 \mu \mathrm{l})$ were incubated with Tris buffer $(0.1 \mathrm{~mol} / \mathrm{l}, 6.65 \mu \mathrm{l}, \mathrm{pH} 7.4)$, PEP $(0.3 \mathrm{mmol} / \mathrm{l})$, $\mathrm{KCl}(60 \mathrm{mmol} / 1), \mathrm{MgCl}_{2}(30 \mathrm{mmol} / \mathrm{l})$, and either pyruvate kinase (E.C.2.7.1.40, $100 \mathrm{U} / \mathrm{ml}$ ) alone or with the addition of myokinase (E.C.2.7.4.3, $76 \mathrm{U} / \mathrm{ml}$ ). The incubations were stopped after $60 \mathrm{~min}$ at $38^{\circ} \mathrm{C}$ by dilution with Tris $(0.1 \mathrm{~mol} / \mathrm{l}, 10.9 \mu \mathrm{l})$ containing EDTA $(5 \mathrm{mmol} / \mathrm{l}, \mathrm{pH} 8.0)$. Blanks and standards were run through the identical procedures.

\section{Determinations of Specific Radioactivities}

The cpm value in each nucleotide fraction separated by thin-layer chromatography was converted to $\mu \mathrm{Ci}$ by counting a $2-{ }^{3} \mathrm{H}$-adenosine standard under identical quenching conditions. For the calculations of the specific radioactivites the values of the total intracellular nucleotide contents given in Table 3 were used. The SEM for the different specific activities was calculated according to the following formula:

$\mathrm{SEM}_{\mathrm{i} / \mathrm{j}}=\left[\left[\frac{\mathrm{SDi}}{\mathrm{xi}}\right]^{2}+\left[\frac{\mathrm{S} \mathrm{Di}_{\mathrm{j}}}{\mathrm{x} j}\right]^{2} \times\left[\frac{\mathrm{xi}_{\mathrm{i}}}{\overline{\mathrm{x}} \mathrm{j}}\right]^{2}\right]^{1 / 2} /\left(\mathrm{min} / \mathrm{n}_{\mathrm{i}}, \mathrm{n}_{\mathrm{j}}\right)^{1 / 2}$

where SDi equals the standard deviation of the radioactive content of the nucleotide tested, SDj the standard deviation of the total amount of this particular nucleotide, $\bar{x}_{i}$ and $\bar{x}_{j}$ the corresponding means and $n_{i}$ or $n_{j}$ the number of observations.

\section{Results}

\section{Efflux of Radioactivity and Insulin}

There was a significant decrease in the efflux of radioactivity concomitant with an increase in the insulin secretory rate when the islets were challenged with a high glucose concentration $[16.7 \mathrm{mmol} / 1$ (Fig. 1)]. The return to basal conditions (glucose $1.67 \mathrm{mmol} / \mathrm{l}$ ) resulted in an increase of the radioactivity of the effluents and a decrease of the insulin release. The same kinetics of radioactive efflux were observed when challenging islets prelabelled with $2-{ }^{3} \mathrm{H}$-adenosine for $6 \mathrm{~h}$ with glucose $(16.7 \mathrm{mmol} / \mathrm{l})$. When prelabelled islets were challenged with high glucose concentrations in the absence of $\mathrm{Ca}^{2+}$, a similar pattern of radioactive efflux was observed (Fig.1), despite the lack of insulin secretion. It is noteworthy, however, that the inhibition of the radioactive efflux was more marked and that there was no later increase of this efflux after withdrawal of the high glucose stimulation. Perifusion with $\alpha$-ketoisocaproic acid $(10 \mathrm{mmol} / \mathrm{l})$ provoked similar but slightly more pronounced effects on the radioactive efflux and insulin secretion than those observed with high glucose concentrations (Fig. 2).

Addition of pyruvate $(30 \mathrm{mmol} / \mathrm{l})$ to the low glucose medium resulted in a fall of the radioactive efflux without any parallel increase of the insulin secretion (Fig. 3). Neither glutamine $(10 \mathrm{mmol} / \mathrm{l})$ nor 3-0-methylglucose $(16.7 \mathrm{mmol} / \mathrm{l})$ influenced the efflux of radioactivity or 


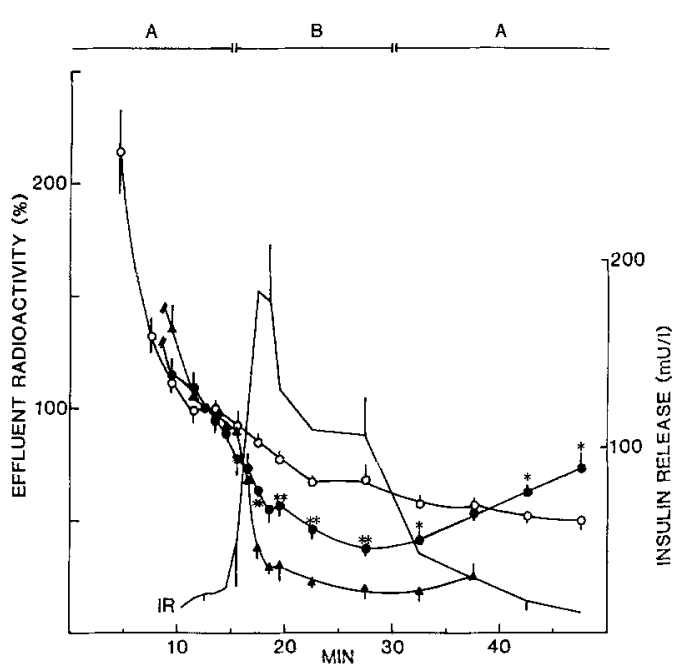

Fig. 1. Effects of glucose $(16.7 \mathrm{mmol} / \mathrm{l})$ on the efflux of radioactivity from 75-125 perifused cultured islets prelabelled with $2-{ }^{3} \mathrm{H}$-adenosine. The horizontal bars $A$ denote basal conditions (glucose $1.67 \mathrm{mmol} / \mathrm{l}$ ) and $B$ shows the stimulation period with high glucose $(16.7 \mathrm{mmol} / \mathrm{l})$ for islets perifused in the normal perifusion buffer $(0)$ or in a buffer lacking calcium chloride ( $\mathbf{\Delta})$. The control efflux with glucose $(1.67 \mathrm{mmol} / 1)$ present all the time in the normal perifusion buffer is also shown (O). All values are expressed in percentages of the average minute efflux value between minutes $11-15$. Serial 2 min samples were taken during the first $10 \mathrm{~min}$, after which ten $1 \mathrm{~min}$ samples were taken. The final samples were taken at $5 \mathrm{~min}$ intervals. The values are expressed as mean \pm SEM for four to six experiments. Samples from the islets subjected to glucose stimulation were analyzed for insulin release $(I R)$ and the SEM for every third value is shown. The insulin release values for control efflux or efflux in the absence of calcium chloride are not shown. ${ }^{*} p<0.05,{ }^{* *} p<0.01$ against control value

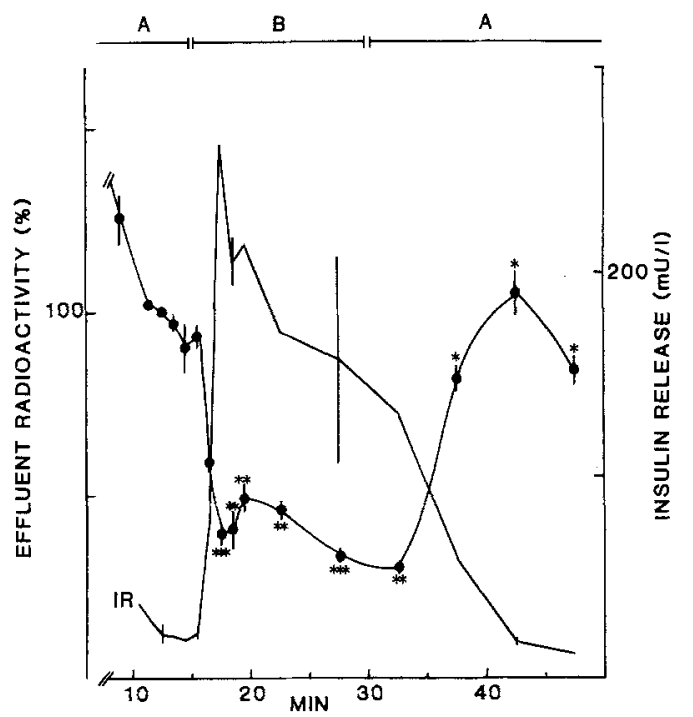

Fig. 2. Effects of $\alpha$-ketoisocaproic acid $(10 \mathrm{mmol} / \mathrm{l})$ on the efflux of radioactivity from prelabelled cultured islets. The horizontal bars $A$ show perifusion at glucose $(1.67 \mathrm{mmol} / \mathrm{l})$ and $B$ denotes the stimulation period with glucose $(1.67 \mathrm{mmol} / 1)$ plus $\alpha$-ketoisocaproic acid $(10 \mathrm{mmol} / 1)$. Samples were taken as in Figure 1 . The concomitant insulin release $(I R)$ with every third SEM is also shown. The efflux values are expressed as mean \pm SEM for five experiments in percentages of the average minute efflux rate between minutes 11-15. Islets $(n=100)$ were used. ${ }^{*} p<0.05,{ }^{* *} p<0.01,{ }^{* * *} p<0.001$ against control value

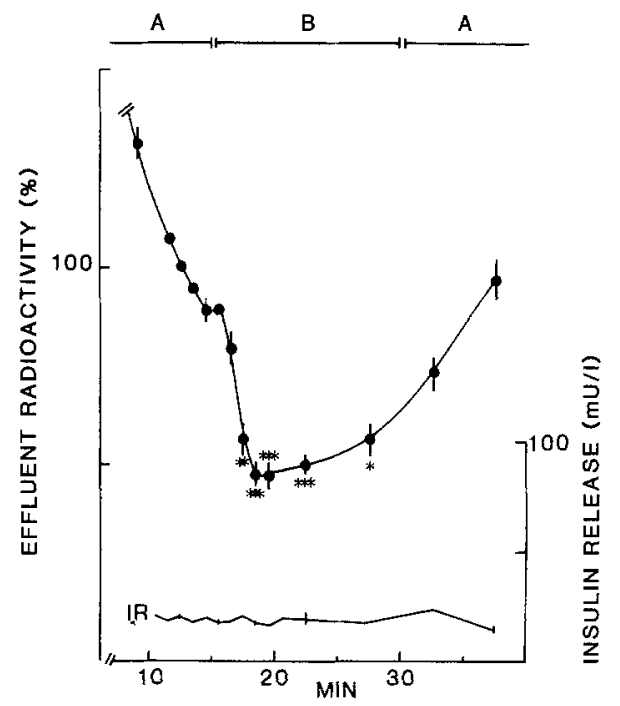

Fig.3. Effects of pyruvate $(30 \mathrm{mmol} / \mathrm{l})$ on the efflux of radioactivity from 75 cultured islets prelabelled with $2{ }^{3} \mathrm{H}$-adenosine. After perifusion in glucose $(1.67 \mathrm{mmol} / \mathrm{l}, A)$, pyruvate $(30 \mathrm{mmol} / 1)$ was added $(B)$ after which there was a return to basal conditions $(A)$. Samples were taken as in Figure 1. Results are expressed as mean \pm SEM for six experiments in percentages of the average minute efflux rate between minutes 11-15. The mean insulin release $(I R)$ values are shown with every third SEM. ${ }^{*} p<0.05,{ }^{* *} p<0.01,{ }^{* * *} p<0.001$ against control value

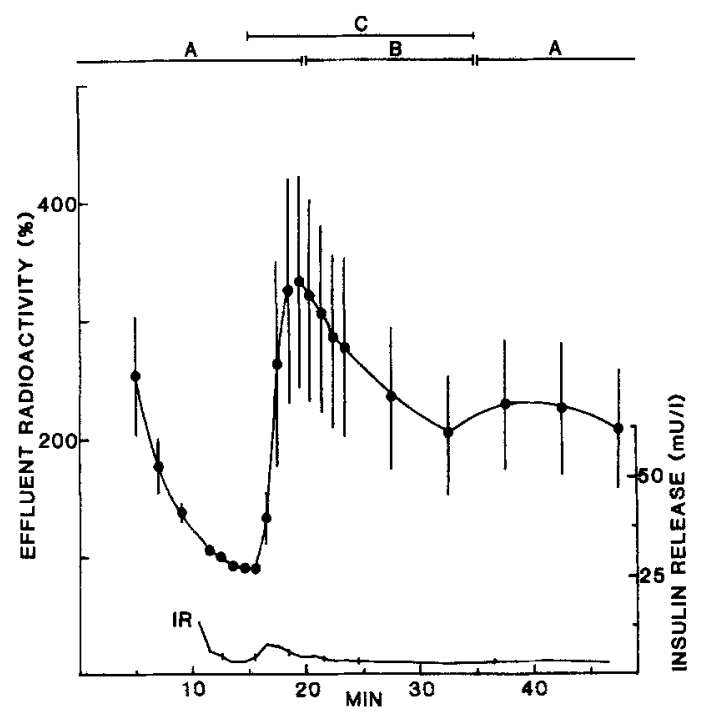

Fig.4. Effects of antimycin $A(10 \mu \mathrm{mol} / 1)$ on radioactive efflux and in. sulin release of cultured islets prelabelled with $2-{ }^{3} \mathrm{H}$-adenosine. Islets $(n=75)$ were pre-incubated as described in Figure 1. After $15 \mathrm{~min}$ of perifusion in glucose $(1.67 \mathrm{mmol} / 1, A)$, antimycin $\mathrm{A}(10 \mu \mathrm{mol} / \mathrm{l})$ was added to the medium $(C)$. The glucose concentration was increased after a further $5 \mathrm{~min}$ to $16.7 \mathrm{mmol} / \mathrm{l}(B)$. Both antimycin $A$ and the high glucose challenge were withdrawn $15 \mathrm{~min}$ later. Results are expressed as mean \pm SEM for six experiments in percentages of the average minute efflux rate between minutes $11-15$. The insulin concentrations (IR) of the effluents with every third SEM are shown 


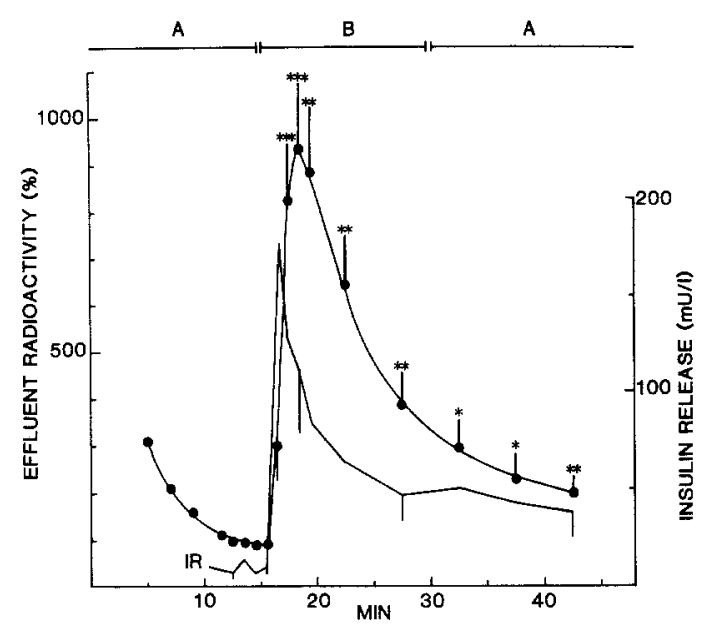

Fig.5. Effects of glipizide $(1 \mu \mathrm{g} / \mathrm{ml})$ on radioactive efflux and insulin release of cultured islets pre-incubated with $2 \cdot{ }^{3} \mathrm{H}$-adenosine. Islets ( $n$ $=75$ ) were pre-incubated as described in Figure 1 . The islets were perifused in glucose $(5.5 \mathrm{mmol} / 1)$ for $15 \mathrm{~min}(A)$. Thereafter the medium was supplemented with glipizide $(B)$ for $15 \mathrm{~min}$ after which there was a return to basal conditions. Results are expressed as mean \pm SEM for four experiments in percentages of the average minute efflux rate between minutes 11-15. Means of the insulin release values $(I R)$ with every third SEM are shown. ${ }^{*} p<0.05,{ }^{* *} p<0.01,{ }^{* *} p<0.001$ against control values

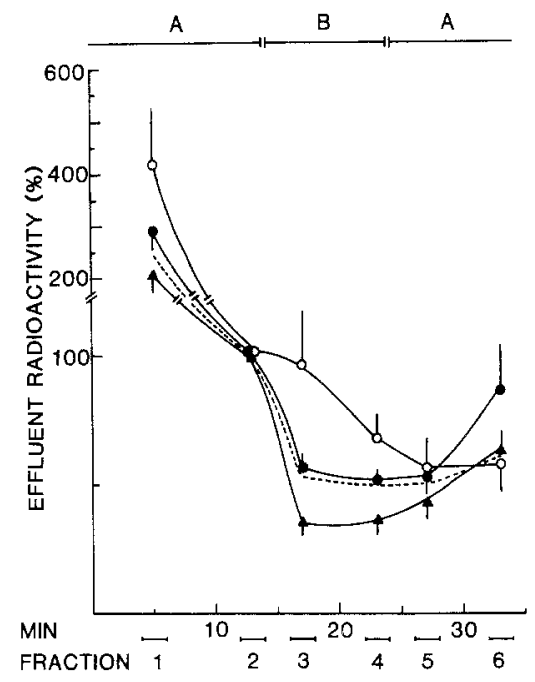

Fig. 6. Separation of the radioactive effluents with respect to ATP, ADP and AMP. Cultured islets $(n=150)$ were pre-incubated as described in Table 1. The values for each nucleotide after separation are expressed as percentages of the values for fraction 2 (taken at glucose $1.67 \mathrm{mmol} / 1$ just before glucose $16.7 \mathrm{mmol} / 1$ stimulation). The ATP (O), ADP ( $)$ and $\operatorname{AMP}(\boldsymbol{\Lambda})$ values, as well as the total radioactive changes $(--)$ are given as mean \pm SEM for six to eight experiments

Table 1. The percentage distribution of radioactive nucleotides and inosine in the effluents of perifused islets prelabelled with $2-{ }^{3} \mathrm{H}-$ adenosine

\begin{tabular}{|c|c|c|c|c|c|c|}
\hline & $\begin{array}{l}\text { Fraction } 1 \\
(\min 5-6) \text { glucose } \\
1.67 \mathrm{mmol} / 1(\%)\end{array}$ & $\begin{array}{l}\text { Fraction } 2 \\
\text { (min 13-14) glucose } \\
1.67 \mathrm{mmol} / 1(\%)\end{array}$ & $\begin{array}{l}\text { Fraction } 3 \\
(\mathrm{~min} 17-18) \text { glucose } \\
16.7 \mathrm{mmol} / 1(\%)\end{array}$ & $\begin{array}{l}\text { Fraction } 4 \\
(\min 23-24) \text { glucose } \\
16.7 \mathrm{mmol} / 1(\%)\end{array}$ & $\begin{array}{l}\text { Fraction } 5 \\
\text { (min } 27-28) \text { glucose } \\
1.67 \mathrm{mmol} / 1(\%)\end{array}$ & $\begin{array}{l}\text { Fraction } 6 \\
\text { (min 33-34) glucose } \\
1.67 \mathrm{mmol} / 1(\%)\end{array}$ \\
\hline ATP & $29.3 \pm 6.9$ & $18.2 \pm 3.6$ & $33.2 \pm 5.8$ & $29.1 \pm 6.7$ & $20.8 \pm 4.6$ & $21.7 \pm 5.4$ \\
\hline ADP & $28.0 \pm 2.1$ & $25.9 \pm 3.6$ & $32.5 \pm 3.7$ & $29.9 \pm 3.3$ & $29.6 \pm 4.4$ & $34.2 \pm 5.3$ \\
\hline AMP & $29.4 \pm 5.5$ & $38.4 \pm 4.7$ & $22.1 \pm 2.4$ & $23.7 \pm 3.4$ & $29.4 \pm 3.3$ & $28.1 \pm 3.3$ \\
\hline Inosine & $8.2 \pm 2.6$ & $7.6 \pm 2.1$ & $3.3 \pm 1.3$ & $4.1 \pm 2.6$ & $6.8 \pm 3.2$ & $8.9 \pm 3.7$ \\
\hline
\end{tabular}

Cultured islets $(n=3150)$ were prelabelled and perifused for $14 \mathrm{~min}$ at glucose $(1.67 \mathrm{mmol} / \mathrm{l})$ before changing to glucose $(16.7 \mathrm{mmol} / 1)$ for $10 \mathrm{~min}$ and finally returning to basal conditions. Two min fractions taken at the time intervals described in the top of the table were frozen and freeze-dried before separation by thin-layer chromatography (Methods section). Values represent mean \pm SEM for seven to eight experiments expressed as percentage of the total radioactivity in each effluent sample

the insulin release when added during perifusion. Islets isolated from starved mice did not respond with an increased rate of insulin secretion when challenged with high glucose levels or leucine, whereas the addition of theophylline to the high glucose medium partly restored the stimulatory effect of glucose. Under all these circumstances, the pattern of the radioactive efflux was almost identical whether islets from fed or fasted mice were employed.

Addition of antimycin A $(10 \mu \mathrm{mol} / \mathrm{l})$ to the low glucose medium caused a prompt increase in the radioactive efflux, which was not influenced by increasing the glucose concentration (Fig. 4). The rate of insulin secretion was unchanged after the antimycin A supplementation. In order to ensure a stimulatory effect of glipizide on the insulin secretory rate, experiments with this com- pound were performed with a basal medium containing glucose $(5.5 \mathrm{mmol} / \mathrm{l})$. It was found that the initial peak of insulin secretion in response to the glipizide stimulation was accompanied by a marked parallel increase of the radioactive efflux (Fig. 5). The times at which the maximum values of these variables occurred, however, differed in that the peak insulin secretion value preceded by $2 \mathrm{~min}$ that of the radioactive efflux. The withdrawal of glipizide from the perifusion medium did not affect the rates of insulin secretion and radioactive efflux.

\section{Radioactive Components of the Effluents}

As shown in Table 1, adenine nucleotides and inosine constitute $>90 \%$ of the total radioactivity in the effluents. When challenging the prelabelled islets with high 
Table 2. Separation of trichloro-acetic acid extracts of perifused islets prelabelled with $2-{ }^{3} \mathrm{H}$-adenosine

\begin{tabular}{llllll}
\hline Perifusion conditions & ATP $(\%)$ & ADP $(\%)$ & AMP $(\%)$ & Inosine (\%) & Adenosine $(\%)$ \\
\hline Glucose $1.67 \mathrm{mmol} / 1$ & $67.8 \pm 2.8$ & $17.4 \pm 2.4$ & $11.2 \pm 1.0$ & $2.3 \pm 0.4$ & $1.0 \pm 0.2$ \\
Glucose $16.7 \mathrm{mmol} / 1$ & $81.1 \pm 3.2^{\mathrm{a}}$ & $10.1 \pm 1.9^{\mathrm{a}}$ & $4.6 \pm 1.0^{\mathrm{b}}$ & $1.0 \pm 0.2^{\mathrm{a}}$ & $0.5 \pm 0.1^{\mathrm{a}}$ \\
Glucose $1.67 \mathrm{mmol} / 1$ & $68.9 \pm 2.9^{\mathrm{c}}$ & $15.3 \pm 2.2$ & $9.1 \pm 1.3^{\mathrm{c}}$ & $1.9 \pm 0.2^{\mathrm{d}}$ & $0.9 \pm 0.1^{\mathrm{d}}$ \\
Glucose $1.67 \mathrm{mmol} / 1+$ & $61.2 \pm 5.1$ & $23.0 \pm 4.8$ & $14.1 \pm 3.3$ & $1.3 \pm 0.5$ & -
\end{tabular}

Cultured islets $(n=125)$ were perifused under different conditions and then extracted and the metabolites separated. The results are expressed as mean \pm SEM for five to seven experiments and show the radioactivity in each nucleotide and nucleoside pool expressed as percentages of the total radioactivity. Line 1 shows the distribution of radioactivity from islets perifused for $15 \mathrm{~min}$ with glucose $(1.67 \mathrm{mmol} / 1)$, whereas line 2 demonstrates the effects of an additional $5 \mathrm{~min}$ perifusion with glucose $(16.7 \mathrm{mmol} / 1)$. Line 3 gives the result of experiments in which the islets were perifused for $15 \mathrm{~min}$ with glucose $(1.67 \mathrm{mmol} / \mathrm{l})$, then for $15 \mathrm{~min}$ with glucose $(16.7 \mathrm{mmol})$ and finally for $20 \mathrm{~min}$ at basal conditions. Results in line 4 are from experiments in which the islets were exposed to pyruvate $(30 \mathrm{mmol} / 1)$ in glucose $(1.67 \mathrm{mmol})$ for $5 \mathrm{~min}$ after $15 \mathrm{~min}$ low glucose perifusion. ${ }^{\mathrm{a}} p<0.05$ and ${ }^{\mathrm{b}} p<0.01$ when tested against corresponding values in line $1 ;^{\circ} p<0.05$ and ${ }^{\mathrm{d}} p<0.01$ when tested against corresponding values in line 2

glucose $(16.7 \mathrm{mmol} / \mathrm{l})$, the percentage of ATP increased significantly $(p<0.05)$, concomitant with a marked decrease in the AMP content $(p<0.05)$. In an attempt to visualize how the different nucleotides contributed to the radioactive efflux at different time intervals during the perifusion, the figures were expressed in reference to those obtained just before the high glucose challenge (Fig.6). All nucleotides decreased markedly as did the total radioactive efflux during the first low-glucose equilibration period. With the addition of high glucose concentrations, the amounts of AMP and ADP decreased further during the first $4 \mathrm{~min}$, but then remained constant. The ATP level, however, did not increase initially but subsequently gradually declined.

\section{Radioactive Components of Islet Trichloroacetic Acid Extracts}

Table 2 shows that the intracellular islet content of labelled ATP increased after the high glucose challenge concomitant with decreases in all other components (ADP, AMP, inosine and adenosine). The inverse reaction was observed when the glucose concentration of the perifusion medium was again decreased. Pyruvate addition to the low glucose medium, however, did not affect the islet content of the different nucleotides and nucleosides.

\section{Nucleotide Concentrations of Batch-Incubated Islets}

A bioluminescence assay was used to determine the adenine nucleotide content of islets incubated for $15 \mathrm{~min}$ in glucose $(1.67 \mathrm{mmol} / \mathrm{l})$ with or without a subsequent $5 \mathrm{~min}$ incubation in glucose $(16.7 \mathrm{mmol} / \mathrm{l})$ (Table 3$)$. Again, a marked increase of the ATP concentration was observed in response to the high glucose stimulation, which was accompanied by a substantial decrease of the AMP concentration. The ADP concentration was not significantly influenced by the increased glucose concentration. Addition of pyruvate to the low glucose medium did not change the ATP concentration of the islets (results not shown).
Table 3. Effects of glucose on nucleotide concentrations of batch incubated islets

\begin{tabular}{lcccl}
\hline $\begin{array}{l}\text { Glucose } \\
\text { concentration }\end{array}$ & ATP $(\%)$ & ADP $(\%)$ & AMP $(\%)$ & $\begin{array}{l}\text { Total } \\
\text { nucleotide } \\
\text { content } \\
\text { (pmol/islet) }\end{array}$ \\
\hline $1.67 \mathrm{mmol} / 1$ & $56.1 \pm 4.3$ & $22.2 \pm 4.9$ & $21.7 \pm 3.6$ & $8.0 \pm 1.2$ \\
$16.7 \mathrm{mmol} / 1$ & $75.9 \pm 3.5^{\mathrm{a}}$ & $16.2 \pm 3.0$ & $7.9 \pm 2.0^{\mathrm{a}}$ & $9.2 \pm 1.6$ \\
\hline
\end{tabular}

Ten cultured islets were incubated at $37^{\circ} \mathrm{C}$ for $15 \mathrm{~min}$ in a Hepesbuffered Krebs-Ringer bicarbonate solution containing glucose $(1.67 \mathrm{mmol} / \mathrm{l})$ and albumin $(0.5 \mathrm{mg} / \mathrm{ml})$. The islets were then either rapidly frozen or transferred to a new medium containing glucose $(16.7 \mathrm{mmol} / 1)$ for $5 \mathrm{~min}$ before being frozen. The islets were then freeze dried before nucleotide analyses by a luciferase technique (Methods section). The results are expressed as mean \pm SEM for six experiments. ${ }^{\mathrm{a}} p<0.01$ when tested against glucose $(1.67 \mathrm{mmol} / \mathrm{l})$

Table 4. The specific radioactivities of the intracellular adenine nucleotides

\begin{tabular}{llll}
\hline Experimental conditions & ATP & ADP & AMP \\
\hline Glucose $1.67 \mathrm{mmol} / 1$ & $283.6 \pm 35.5$ & $171.0 \pm 43.7$ & $122.2 \pm 23.2^{\mathrm{a}}$ \\
Glucose $16.7 \mathrm{mmol} / 1$ & $256.7 \pm 53.8$ & $172.3 \pm 21.7$ & $142.0 \pm 43.7$ \\
\hline
\end{tabular}

Specific activities were determined on 125 islets prelabelled with $2-{ }^{3} \mathrm{H}$ adenosine $(2.5 \mathrm{Ci} / \mathrm{mmol})$ for $45 \mathrm{~min}$. The experimental conditions at the two glucose concentrations were as those given in Table 2 including extraction and separation by thin-layer-chromatography of the radioactivity. The results are expressed as mean $\pm \mathrm{SEM}$ in $\mathrm{Ci} / \mathrm{mol}$ for five experiments. ${ }^{a}$ denotes $p<0.01$ when tested against ATP specific activity at glucose $1.67 \mathrm{mmol} / \mathrm{l}$

\section{Determination of Specific Radioactivities}

The increase of the glucose concentration did not affect the specific radioactivity in any of the adenine nucleotides (Table 4). Moreover, the specific radioactivities of all nucleotides were the same apart from ATP and AMP values at glucose $(1.67 \mathrm{mmol} / 1)$. This difference may reflect the methodological difficulties in determining total intracellular AMP content. 


\section{Discussion}

The present study shows that an efflux of radioactive nucleotides occurs from islet cells prelabelled with $2-{ }^{3} \mathrm{H}-$ adenosine. It was also found that in some experiments changes of the efflux pattern were inversely correlated to changes in the rate of insulin secretion as induced by glucose. The findings that the intracellular specific radioactivity of ATP, ADP and AMP were approximately the same, both at low and high glucose concentrations, suggest that within $45 \mathrm{~min}$ the radioactivity had equilibrated within the (major) intracellular adenine nucleotide pools. Moreover, there was an almost total correspondance between the decrease of the intracellular AMP and ADP concentrations and that of the radioactive AMP and ADP efflux in response to glucose. Against this background it seems plausible that the glucose-induced alterations of radioactivity efflux reflected changes of the cytoplasmic AMP and ADP concentrations. In order to substantiate further this hypothesis, determinations of the specific radioactivities of the effluent nucleotides would be needed. Unfortunately, no sufficiently sensitive techniques were available for this purpose. The finding that 6-h prelabelled islets displayed a similar glucoseinduced efflux pattern as those of 45-min prelabelled cells, nevertheless, speaks in favour of the above mentioned hypothesis, since the long-term prelabelling with $2-{ }^{3} \mathrm{H}$-adenosine probably gives a complete intracellular equilibration of radioactivity.

Similar responses in the radioactivity efflux pattern were observed after addition of two other metabolizable secretagogues, $\alpha$-ketoisocaproic acid and leucine, whereas no response to the metabolized non-initiating secretagogue glutamine was observed [16]. A discrepancy between insulin release and our observed radioactivity efflux pattern was, however, seen when pyruvate was added. Pyruvate has previously been shown not to affect the levels of nucleotides in islets [18]. It also did not affect the concentrations of labelled intracellular nucleotides of trichloro-acetic acid extracted islets compared to controls in this study. It must therefore be assumed that the observed effects of pyruvate on the efflux of radioactivity were due to changes in the membrane permeability or intracellular distribution of nucleotides.

We have recently described an impaired insulin release in response to both glucose and leucine after starvation (unpublished observations), although only the metabolism of glucose was found to be inhibited. Our present findings of 'normal' radioactive efflux patterns in response to both glucose and leucine, despite the strongly suppressed insulin release, suggests that the metabolic step responsible for the changes in intracellular nucleotide concentrations evoked by glucose or leucine is not influenced by starvation.

Antimycin A, an inhibitor of islet cell respiration [10], and glipizide, a sulphonylurea, both increased the rate of radioactive efflux from perifused, prelabelled islets. The observed effect of antimycin A was expected, since inhi- bitors of islet respiration may increase the intracellular AMP levels [15]. The stimulation of radioactive efflux observed after stimulation by glipizide was, however, somewhat surprising. It is perhaps relevant here that it has been proposed that certain sulphonylureas have ionophoretic properties in islets [5]. The functional significance of the increased radioactive efflux in response to glipizide remains, however, unclear. An increased efflux of nucleotides could, however, explain the previous observations of decreased ATP-concentrations [8] and inhibited glucose-stimulation of proinsulin biosynthesis [4] in islets exposed to sulphonylurea.

With the present experimental design it is possible to obtain only an indirect picture of the kinetics of changes in the intracellular AMP or ADP concentrations. The efflux curves reported in this study are highly suggestive of a possible coupling between early metabolic events, which affect the intracellular concentrations of nucleotides and the rate of insulin release when metabolizable secretagogues are added. Thus, the possibility exists that the specific effects on nucleotide concentrations, evoked by glucose, $\alpha$-ketoisocaproic acid and leucine which gave rise to the observed efflux pattern, may play an important role in regulating other metabolic parameters. One such important parameter may be the redox ratio of the pancreatic islets which has been suggested to be a coupling factor between glucose recognition and insulin release $[6,14]$. This suggestion does not necessarily contradict previous reports on different kinetics of glucoseinduced insulin release and changes in intracellular nucelotide levels [15], since such a mechanism would precede other metabolic events and thus play a permissive role.

Acknowledgements. The skilled technical assistance of E. Forsbeck, M. Lindfors and A. Nordin is gratefully acknowledged. Financial support was received from the Swedish Medical Research Council $(12 \times-109 ; 12 \times-535)$, the Swedish Diabetes Association and the Medical Faculty, University of Uppsala, Uppsala, Sweden. Discussions and critical reviewing of the manuscript by Drs. A. Andersson and C.Hellerström is gratefully appreciated.

\section{References}

1. Andersson A (1978) Opposite effects of starvation on oxidation of ${ }^{14} \mathrm{C}$-adenosine and adenosine-induced insulin release by isolated mouse pancreatic islets. Biochem J 176: 619-621

2. Andersson A (1978) Isolated mouse pancreatic islets in culture: Effects of serum and different culture media on the insulin production of the islets. Diabetologia 14: 397-404

3. Andersson A (1980) Nucleoside-stimulated insulin production by isolated mouse pancreatic islets. Horm Metab Res Suppl 10:14-19

4. Andersson A, Borg LAH (1980) Effects of glipizide on the insulin production by isolated mouse pancreatic islets. Acta Endocrinol Suppl 239:37-41

5. Couturier E, Malaisse WJ (1980) Insulinotropic effects of hypoglycaemic and hyperglycaemic sulphonamides: the ionophoretic hypothesis. Diabetologia 19:335-340

6. Hedeskov CJ (1980) Mechanism of glucose-induced insulin secretion. Physiol Rev 60: 442-509

7. Heding L (1972) Determination of total serum insulin (IRI) in insulin-treated diabetic patients. Diabetologia 8:260-266 
8. Hellman B, Idahl L-Å, Danielsson $\AA$ (1969) Adenosine triphosphate levels of mammalian pancreatic B-cells after stimulation with glucose and hypoglycemic sulfonylureas. Diabetes 18: 509-516

9. Howell S, Taylor K (1968) Potassium ions and the secretion of insulin by islets of Langerhans incubated in vitro. Biochem $\mathrm{J} 108: 17-24$

10. Hutton JC, Malaisse WJ (1980) Dynamics of $\mathrm{O}_{2}$ consumption in rat pancreatic islets. Diabetologia 18:395-405

11. Ismail NA, Denshary ESM, Montague W (1977) Adenosine and the regulation of insulin secretion by isolated rat islets of Langerhans. Biochem J 164: 409-413

12. Jain K, Logothetopoulos J (1978) Metabolic signals produced by purine ribonucleosides stimulate proinsulin biosynthesis and insulin secretion. Biochem J 170: 461-467

13. Lernmark Â, Söderberg L-A, Täljedal I-B (1979) 5-AMP hydrolysis by suspensions and homogenates of pancreatic islet cells from normal and cortisone-treated rats. Histochemistry 63: 155-161

14. Malaisse WJ, Sener A, Herchuelz A, Hutton JC (1979) Progress in endocrinology and metabolism. Insulin release: the fuel hypothesis. Metabolism 28: 373-386

15. Malaisse WJ, Hutton JC, Kawazu S, Herchuelz A, Valverde I, Sener A (1979) The stimulus-secretion coupling of glucose-induced insulin release. XXXV. The links between metabolic and cationic events. Diabetologia 16:331-341

16. Malaisse WJ, Sener A, Carpinelli AR, Anjaneyulu K, Lebrun P, Herchuelz A, Christophe J (1980) The stimulus-secretion coupling of glucose-induced insulin release. XLVI. Physiological role of $\mathrm{L}$ glutamine as a fuel for pancreatic islets. Mol Cell Endocrinol 20: 171-189

17. Pearson JD, Carleton JS, Hutchings A, Grodon JL (1978) Uptake and metabolism of adenosine by pig aortic endothelial and smooth-muscle cells in culture. Biochem J 170: 265-271

18. Sener A, Kawazu S, Hutton JC, Boschero AC, Devis G, Somers G, Herchuelz A, Malaisse WJ (1978) The stimulus-secretion coupling of glucose-induced insulin release. Effect of exogenous pyruvate on islet function. Biochem J 176:217-232

19. Welsh M, Andersson A (1981) Adenosine uptake by isolated mouse pancreatic islets. Biochem Pharm 30: 2075-2080

20. Wettermark G, Tegnér L, Brolin SE, Borglund E (1969) Photokinetic measurements of the ATP and ADP levels in isolated islets of Langerhans. In: Falkmer S, Hellman B, Täljedal I-B (eds) The structure and metabolism of the pancreatic islets. Pergamon Press, Oxford, pp 275-282

Received: 7 July 1981

and in revised form: 16 February 1982

Dr. Michael Welsh

Department of Medical Cell Biology

Biomedicum

Box 571

S-751 23 Uppsala, Sweden 